\title{
Personal financial literacy and personal debt management: the potential relationship with new venture creation
}

\author{
*Me. Liezel Kotzè \\ Prof. A.v.A. Smit \\ Department of Business Management \\ University of the Free State \\ kotzel.ekw@mail.uovs.ac.za*
}

*To whom all correspondence should be addressed

\begin{abstract}
Prior research shows that personal savings are one of the most important financial sources for start-ups of entrepreneurial firms. The lack of personal savings and seeming shortage of financial knowledge could contribute to the low incidence of new venture creation, and the high failure rate amongst South African entrepreneurs. This paper investigates the perceptions of 286 Business Management students with a minimum of three years' working and management experience, regarding both their financial literacy and their need and desire for financial education. The outcomes of the study show the necessity for financial education and financial literacy in South Africa. The respondents showed a lack of confidence in their money management skills and expressed a desire for more financial knowledge. It is possible that an increased level of financial literacy could lead to more entrepreneurial activity and a decrease in new venture failures.
\end{abstract}

Key words and phrases: personal financial literacy, personal debt, personal savings, personal financial management, new venture creation

\section{Introduction}

In view of the fact that personal savings represent the principal source of funding used by entrepreneurs to start and grow their entrepreneurial ventures, the extremely low level of savings, combined with the excessive debt levels of individuals in South Africa, is a cause for concern. Personal debt and savings are two key variables in determining effective personal financial management. Healthy personal financial management will be based on good financial knowledge or literacy (Timmons \& Spinelli, 2007:388). Anthes (2004:49) concludes that

financial literacy is the ability to read, analyse, manage and communicate about personal financial conditions that affect material well-being .... the ability to discern financial choices, discuss money and financial issues without (or despite) discomfort, plan for the future, and respond competently to life events that affect everyday financial decisions, including events in the general economy.

According to the US Financial Literacy and Education Commission (Basu, 2005:2), financial literacy is defined as 
the ability to make informed judgements and to take effective actions regarding the current and future use and management of money. Financial literacy should include the ability to understand financial choices, plan for the future, spend wisely and manage and be ready for life events such as job loss or saving for retirement.

The lack of knowledge of financial management contributes to the low prevalence of new venture creation, and ultimately the high failure rate of South African Small and Medium-sized Enterprises (SMEs), as most entrepreneurs are intimidated by financial management (Timmons \& Spinelli, 2007:388). The Global Entrepreneurship Monitor (GEM, 2005:7) confirms the fact that there is a very low incidence of entrepreneurial activity in South Africa. Limited access to finance has been cited as one of the main factors influencing the low level of entrepreneurship. One of the answers to this dilemma could be to provide financial education to empower individuals to effectively manage their personal finances (debt and savings levels) in an attempt to increase entrepreneurship and decrease new venture failures.

This paper will provide background on the escalating problem of inadequate financial management practices due to insufficient financial literacy, and the importance of improving the financial literacy of individuals.

\section{Identification of problem}

The paper will concentrate on investigating the perceptions of individuals regarding their financial literacy and their need for financial education, and the role these play in the finances of both the individual and the entrepreneur.

The Global Entrepreneurship Monitor (GEM) (2003:13) reports lack of financial support as one of the main problems entrepreneurs are faced with in South Africa. This, however, does not account for the low rate of entrepreneurial activity in South Africa compared with that of other developing countries. Entrepreneurs participating in the GEM study indicated that start-up finance depended on personal savings or loans from friends or family. Black-owned registered SMEs in the GEM study indicated that access to finance was only provided if secure financial management was demonstrated. The GEM survey indicated that a significant proportion of the participating firms did not implement proper management practices and that targeted skills development could be beneficial.

According to Timmons and Spinelli (2007:387), the lack of skills in financial analysis and management could be viewed as the entrepreneurs' Achilles heel. Entrepreneurs and management teams find the concept of financial management intimidating. Even highly educated individuals admit to feeling uncomfortable, intimidated and even terrified because of their lack of financial management expertise. The transition from being an entrepreneur to becoming an entrepreneurial manager of a venture can be exceedingly risky if there is little or no confidence in managing finances, as financial management is listed as one of the critical managerial competencies in new venture creation and development (Timmons \& Spinelli, 2007:269). Furthermore, there is an absolute scarcity of financial administration skills amongst previously disadvantaged individuals and 
entrepreneurs in South Africa (Simcock, 2007:21). Personal and venture financial management skills definitely influence the creation of new ventures (Kim, 2001:1), and the lack of financial management knowledge may result in possible failures (Simcock, 2007:21).

There has been an increasing demand for information on personal finance. Research (Kim, 2000:1 and Joo, 1998:34) has shown that many adults lack the financial knowledge to make competent and effective financial choices. The authors therefore assume that if individuals are illiterate concerning their personal finances, their financial management of new ventures will also be lacking and will lead to reduced new venture creation and possible failures of SMEs.

Excessively high debt levels, low saving rates, becoming targets of investment fraud, delinquency on credit cards and bankruptcy have all been found to be related to financial illiteracy in individuals (Kim, 2000:1). Even many developed countries have excessive debt levels and diminishing savings, even though they have abundant wealth and literacy at their disposal compared with developing countries (Anthes, 2004:50). This trend is also evident in South Africa where, after the mid-1980s' deregulation of financial institutions, household debt amplified in excess of 30 percent (Aron \& Muellbauer, 2000:2). According to Tito Mboweni, Governor of the South African Reserve Bank (SARB), household debt as a percentage of disposable income accelerated to 77.4 percent during the third quarter of 2007, leaving only an average of 22.6 percent of the salary for living expenses and savings (SARB, 2007:1). Lorgat (2003:8) argues that South Africans lack a generalised savings culture, one of the causes being manifest financial illiteracy on the part of the consumer. Workers are spending almost all of their income on consumption, resulting in little, if any, of their income being left for savings or investments. This is problematic in South Africa, both on an individual level and in relation to the prospects of economic growth in the country via entrepreneurship. Lack of savings could also impact on long-term government expenditure, as individuals make insufficient provision for old age, an additional burden that the government will have to manage (Janse van Rensburg, 1999:7)

The ratio of household debt to disposable income in South Africa has been fluctuating between 50.6 percent and 71.8 percent between 1996 and 2006. Savings rates, on the other hand, have declined sharply, from as high as 8 percent in 1985 to approximately 0.52 percent of personal disposable income in 2006 (Kane-Berman \& Tempest, 2007:87). Mounting personal debt has caused South Africans' savings to become insufficient, at best. Long-term savings are therefore placed in jeopardy (Grawitzky, 2003:57). Deregulation in South Africa has led to virtually instant higher levels of debt for consumers, with the consequent decrease in savings. South African consumers' saving figures confirm this fact, as the debt levels are higher than ever, with the ensuing low savings statistics, as can be seen in Figure 1. 
Figure 1: Household debt and household savings as a percentage of personal disposable income (1984-2006)

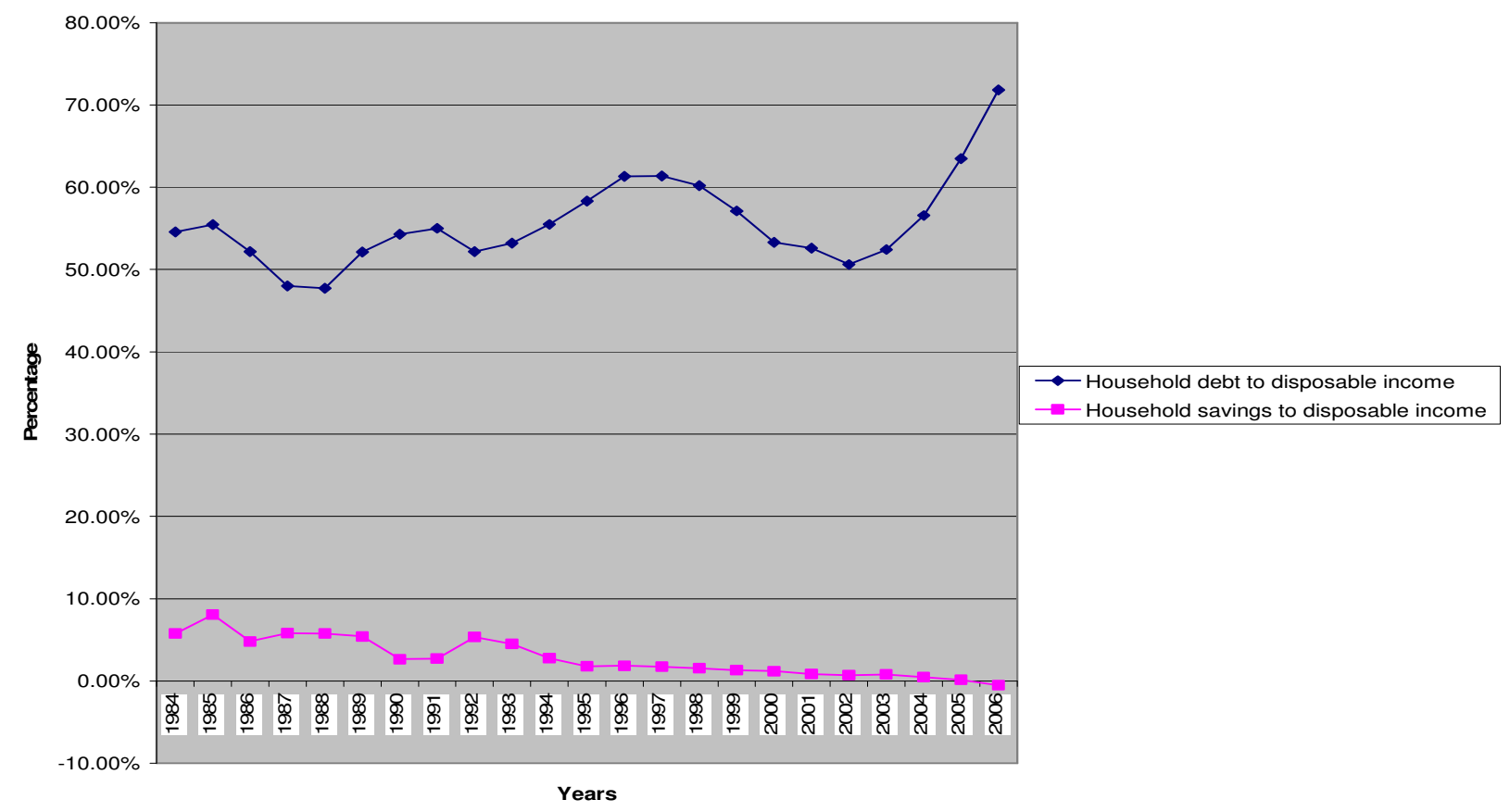

(Source: Kane-Berman \& Tempest, 2007:87).

The very high levels of debt South African individuals accumulate invariably result in decreased savings, as these two variables have an inverse relationship.

Individuals make decisions with regard to their personal finances on a daily basis, and even though these decisions are necessary for day-to-day survival, it can be a daunting task (Karlsson, Dellgran, Lingander \& Gärling 2004:754). Kidwell and Turrisi (2004:601) point out the strong link between the accumulation of personal debt and a distinct lack of skills in money management. Old-fashioned values concerning financial management, such as budgeting and saving, are lost in the pursuit of instant gratification, and consumers tend to spend more than they earn. Streeter (2003:4) adds that consumers tend to be confused and intimidated by the complexity of the finance industry and that they are embarrassed to admit that they struggle to understand certain terminology or practices. These individuals will not be able to select the most effective financial choices available to them, because the subject is unknown to them and therefore seems threatening. It is necessary for individuals to acquire knowledge about personal financial issues in order to be able to evaluate the financial options available to them, manage their finances effectively and gain financial security (Anthes, 2004:52).

Chen and Volpe (1998:121) found that the participants in their research study with better financial knowledge identified more efficient options, while in their decision making concerning personal financial issues they reacted more effectively. The level of an individual's financial knowledge tends to influence attitudes that in turn affect the 
individual's financial behaviour. Inadequate personal financial management skills could be a limiting factor when the individual is creating and managing a new venture.

\section{Literature review}

There are so many financial choices to be made, with so many variables to consider in addition to hidden biases, conflicts and subjective preferences, that consumers can become overwhelmed when it comes to making personal financial decisions (Streeter, 2003:4). It is therefore necessary to examine financial literacy and all its components. A number of factors in the immediate external environment can be identified as factors that can lead to decreasing literacy in individuals. The most pertinent of these are accordingly discussed.

\section{Increased complexity of the economy}

The finance industry tends to be confusing, intimidating and complex. Individuals who are not educated or knowledgeable enough will not be able to make effective financial choices and are sometimes too proud to admit that they do not understand the economic environment. Individuals are not being responsible when it comes to their personal finances, as revealed by Anthes (2004:51), who reports that according to a 2004 Retirement Confidence Survey, only 58 percent of workers are currently saving for retirement, and even these workers do not calculate how much money they have to save to live comfortably by the time they retire. A shocking finding was that half of the workers who are not saving for retirement feel confident that they will have enough retirement money by the time they need it, proving once again that there exists a great need for financial literacy training in South Africa as well as worldwide (Streeter, 2003:4).

\section{Less time accumulating wealth and more time spending}

Countless individuals all over the world are not saving enough money for retirement and are unprepared to deal with the complexities of managing and acquiring assets throughout their working lives (Lloyd, 2005:15). Citizens in South Africa and Western countries are experiencing major financial burdens as a result of increased life expectancy of individuals. In the year 2000, Americans only started accumulating wealth after the age of 25 and stopped long before turning 65. In 1930, by contrast, individuals started accumulating wealth at the age of 20 and continued to do so until they reached their late 60s. Currently individuals spend an average of 35 years in retirement, compared with 20 years of retirement in the 1930s. Therefore, time in retirement has increased, but there has been a distinctive decrease in wealth accumulation (Anthes, 2004:51).

\section{Longer life expectancy}

Citizens in South Africa and Western countries are therefore experiencing major financial burdens as a result of increased life expectancy of individuals. As indicated above, people live much longer than they did a few decades ago and consequently need significantly 
more in terms of retirement savings. In spite of this, however, a large proportion of individuals do not plan for retirement or take their life expectancy into account. The average life expectancy in the United States is expected to increase from 68 in the 1950s to 81 by 2025 (Lloyd, 2005:15). Anthes (2004:51) reports the following statistics concerning US life expectancy:

- In 1900, 7 percent of 60-year old Americans had at least one living parent.

- In 2000, 44 percent of 60-year old Americans had at least one living parent.

\section{Absence of (or possession of limited) financial education}

South Africans lack the necessary financial skills to plan for retirement, and education in this field would be of great benefit to society (Lloyd, 2005:15). Therefore little doubt exists that school syllabuses should include basic financial skills training. However, many schools in the United States do not teach financial education as a subject because the teachers themselves do not understand what they are teaching (Anthes, 2004:51). Effective consumer education will not occur overnight and it is a multi-generational project. It is clear that the government of South Africa recognises the lack of, and need for, financial education (RSA MoF, 2006:5). It is suggested that the school education system should accommodate training to stimulate entrepreneurial consciousness and educate students in necessary financial and business skills (GEM, 2003:13). The educational system should also provide effective financial and administrative training to existing entrepreneurs (GEM, 2003:13).

\section{Lack of pension and personal savings}

Individuals need to save for the following reasons (RSA MoF, 2006:4):

- To improve consumption patterns over their lifetime;

- To provide for their retirement and old age;

- To finance expected large expenditures, for example the purchase of a house, or their children's education;

- To finance unexpected losses of income.

However, the importance of saving is frequently only realised when the need for funds arises and then it is often too late (RSA MoF, 2006:4). Investment and pension returns decreased since the 1980s as a result of (until recently) lower inflation and reduced interest rates. The average life expectancy at birth is 80 years and with this in mind, these investment returns become even more mediocre. The combination of lower interest and inflation rates means that an individual who is currently retired will need double the capital to buy the same standard of living as in the 1980s (Needham, 2005:13). Pension savings in the United States are getting more unsteady on a yearly basis, and with personal savings dangerously declining, there is a clear indication that people do not realise the implications of their actions (Anthes, 2004:51). 


\section{Consequences of financial illiteracy}

\section{Spending more than their income}

Atkinson and Kempson (2004:2) found that young people (aged 18 to 24) in Britain are increasingly over-borrowed, leading to financial difficulties because of financial illiteracy. Workers find themselves in financial crises owing to the need to spend their income on costly goods, such as branded clothes and cell phones, for the purpose of fitting into a society where these goods have become a necessity, rather than a luxury (Lorgat, 2003:6). Anthes (2004:52) supports this viewpoint and refers to the "instant gratification mentality" that individuals possess that lures them into spending more on what they want and do not necessarily need.

\section{The lack of, or insufficient, record keeping}

A study done by Kidwell and Turrisi (2004:606) deduced that budgeting can change spending patterns of individuals through the successful regulation of finances. As a result, unnecessary spending is curbed and budget maintenance is met with a favourable attitude. It was found that 45.6 percent of students with better financial knowledge keep detailed financial records, compared with only 29 percent of the students with inferior financial knowledge. This was confirmed by research conducted by Chen and Volpe (1998:121), in which they suggest that groups who are more knowledgeable regulate their spending patterns and decisions by keeping detailed financial records.

\section{Not planning and implementing a regular investment programme}

According to research done by Chen and Volpe (1998:122), 89.4 percent of financially knowledgeable students view the planning and implementation of a regular investment programme as important. When they were offered an investment situation, 80 percent of the knowledgeable group made the correct investment decision, whereas only 51 percent of the less knowledgeable group made the correct decision. Most consumers are not educated enough to make informed investment decisions, as proved by a survey done by Princeton Research Survey Associates (1999:38) in which 45 percent of the recipients had some financial knowledge and 18 percent of the respondents did not have any knowledge concerning investment planning and implementation.

\section{Making incorrect financial decisions}

Related closely to the above is the fact that the more knowledgeable an individual is concerning personal financial issues, the less likely that individual would be to make inaccurate financial decisions that could lead to financial problems, such as taking out inadequate insurance, exceeding their income and making incorrect investment decisions (Chen \& Volpe 1998:122). Garman, Leech and Grable (1996:165) suggest that negative financial decisions could be rectified or avoided by providing employees with the necessary financial counselling and intelligence to manage their finances in a more effective manner. Consumers who spend more than they earn, who do not keep financial 
records and do not plan and implement regular investment programmes, are individuals who make flawed financial decisions.

\section{Financial literacy programmes}

The aim of any financial literacy programme for adults should be "to enable them, individually and collectively, to understand, and question, the way in which financial institutions, the government and personal and household decision-making connect to shape numerous aspects of their daily lives" (Bond, 2000:72). Consumer education seems to improve the basic financial skills required to raise awareness and understanding, which will lead to improved financial decisions (Bond, 2000:72). Various authors (Joo, 1998:284; Kidwell \& Turrisi, 2004:611; Lorgat, 2003:8; Teichman, Cecconi, Bernheim, Novarro, Monga, DaRosa \& Resnick, 2005:139) suggest that adults and children alike should be educated in financial issues, such as retirement planning, credit, savings, debt consolidation and investment, to equip them with essential financial skills to manage their personal finances effectively. Streeter (2003:4) views financial education as crucial in improving both personal savings and more effective credit use. Research gives the impression that financial illiteracy can only be overcome when implementing financial education programmes for all gender, age, income and educational groups. Furthermore, Lorgat (2003:8) suggests that South African individuals need financial education in the workplace to increase their financial well-being. Joo (1998:284) supports this with his extensive research into workplace financial education combined with financial counselling sessions. He found that these improved attitudes and behaviours related to personal finances, which in turn led to positive personal financial outcomes and an improvement in overall financial well-being.

\section{Research objectives and hypotheses}

The literature review identified and discussed the factors that perpetuate or increase financial illiteracy and the consequences of financial illiteracy. Against this background, the empirical analysis focused on determining certain perceptions of individuals regarding their personal finances, with specific reference to financial knowledge, control and confidence. The following hypotheses were formulated:

Hypothesis 1: Adequate financial knowledge is positively related to control of personal finances.

Hypothesis 2: Adequate financial knowledge is positively associated with the management of money to achieve financial goals.

Hypothesis 3: Adequate financial knowledge is positively associated with making independent investment decisions (i.e. without the assistance of a financial planner).

The need for financial education was also investigated. 


\section{Research methodology}

\section{Research design}

The methodology used in this study consisted of primary data, which were obtained from questionnaires; and secondary data, from articles, unpublished reports, academic journals, the Internet, newspapers and other local and international publications. In South Africa very limited research is available in this area; therefore, much use was made of secondary data, for example newspaper articles.

\section{Target population}

The target population comprised all 286 of the adult students enrolled at the University of the Free State School of Management during 2005, where individuals were registered for one of three management and business courses. In order to make provision for a nonresponse, it was decided to use the whole population, which eliminated the need to select a sample. Due to the fact that all individuals in the population had a non-zero probability of selection, each member of the population had an equal opportunity of being selected.

The population was selected on the basis of their business background and education, as all the respondents were employed, either in the private sector or self-employed. The population also had financial management modules included their studies and therefore it can be assumed that their financial management skills would be above average. As these individuals had higher education levels, and education impacts on the management of personal finances, it can be deduced that the results would have been more severe for less educated individuals.

\section{Data collection}

The questionnaire employed (Kim, 2000:337) was adapted for the study. The questionnaires aimed to verify and determine certain attitudes and perceptions amongst individuals regarding personal financial management. Questions measured the level of satisfaction on a Likert-type scale. Answers varied between one and five: very satisfied (1); slightly satisfied (2); uncertain (3); slightly dissatisfied (4) and very dissatisfied (5).

\section{Data analysis}

SPSS (version 15.0 for Windows) was used in the statistical analysis of the data. Means, standard deviation, correlation and frequency distributions were calculated to ascertain and to verify the attitudes and perceptions of the respondents. 


\section{Results}

\section{Sample description}

The gender of the 286 respondents was roughly equally matched, with males representing 52.4 percent and the female respondents representing 47.6 percent. The respondents were predominantly highly educated (65.4 percent had university or technikon degrees or diplomas). The ages of 77.3 percent of the respondents fell between 30 and 49 years.

\section{Attitudes and perceptions regarding personal finances}

In order to determine certain perceptions and attitudes towards personal financial issues, such as adequate knowledge, control and confidence, respondents were asked to grade themselves in terms of their financial literacy on a scale from 1 to 5. From the answers it was possible to deduce a mean for each statement. The percentage of the respondents who were dissatisfied with the four elements (see Table 1) regarding their personal finances was determined by calculating the overall percentage of the respondents that displayed dissatisfaction towards statements in the questionnaire, thus positioning their answers to the specific attitude as the two most negative figures.

Table 1: Level of dissatisfaction and the percentage of respondents dissatisfied with regard to the different attitudes

\begin{tabular}{|l|c|c|}
\hline Attitudes & $\begin{array}{c}\text { Level of } \\
\text { dissatisfaction }\end{array}$ & $\begin{array}{c}\text { Dissatisfied } \\
\text { percentage }\end{array}$ \\
\hline I feel I have adequate knowledge to manage my personal finances & $45.0 \%$ & $27.6 \%$ \\
\hline I feel I have control over my personal finances & $47.5 \%$ & $33.9 \%$ \\
\hline I am confident in managing money to achieve financial goals & $47.5 \%$ & $31.8 \%$ \\
\hline I feel confident in making investment decisions & $50.0 \%$ & $36.0 \%$ \\
\hline
\end{tabular}

The overall level of dissatisfaction towards the various attitudes varied between 45 percent and 50 percent. However, it is interesting to note that approximately 28 percent of the respondents felt that they did not have adequate financial knowledge and 34 percent believed they did not have control over their personal finances.

Two-tailed Pearson Correlation Coefficient was conducted to establish the relationship between adequate financial knowledge and personal finances, confidence in managing money to achieve financial goals, and confidence in making independent investment decisions. The results are illustrated in Table 2: 
Table 2: Pearson Correlation coefficient between adequate financial knowledge and other variables (two-tailed) $(\mathrm{N}=286)$

\begin{tabular}{|l|c|c|}
\hline \multicolumn{1}{|c|}{ Variable } & \multicolumn{1}{|c|}{$\begin{array}{c}\text { Adequate financial } \\
\text { knowledge }\end{array}$} & $\boldsymbol{p}$ \\
\hline Adequate financial knowledge & 1.000 & .000 \\
\hline Control over personal finances & $0.707^{* *}$ & .000 \\
\hline $\begin{array}{l}\text { Confidence in managing money to achieve } \\
\text { financial goals }\end{array}$ & $0.706^{* *}$ & .000 \\
\hline $\begin{array}{l}\text { Confidence in making independent } \\
\text { investment decisions }\end{array}$ & $0.266^{* *}$ & \\
$* * * 0.001$ & \multicolumn{2}{|l}{} \\
\hline
\end{tabular}

Table 2 shows a strong positive correlation between adequate financial knowledge and the other three variables. It can therefore be stated that individuals who perceive themselves as having adequate financial knowledge have a positive significant correlation regarding personal finances; confidence in managing money to achieve financial goals and confidence in making independent investment decisions (i.e. without the assistance of a financial planner).

With $\mathrm{N}=286$, the significance has to be interpreted conservatively (Hair, Anderson, Tatham \& Black, 2008). It is suggested that the common variances of the different correlations with "adequate financial knowledge" are calculated as $100 \mathrm{r}^{2}$. Only relationships above 25 percent common variance are regarded as conceptually significant.

These calculations are presented in the following table:

Table 3: $100 \mathrm{r}^{2}$

\begin{tabular}{|l|c|}
\hline \multicolumn{1}{|c|}{ Variable } & Adequate financial knowledge \\
\hline Control over personal finances & $50 \%$ \\
\hline Confidence in managing money & $50 \%$ \\
\hline Confidence in making investment decisions & $7 \%$ \\
\hline
\end{tabular}

The 7 percent common variance between adequate financial knowledge and confidence in making investment decisions should therefore be interpreted as non-significant, in order not to lend the interpretation to a Type 1 error.

Though the common variance between adequate financial knowledge and confidence in making investment decisions is a mere 7 percent, a further t-test evaluation, as suggested by Janda (2001), indicates a significant correlation at the 99 percent level of confidence. The t-test value is described in Table 4. 
Table 4: Computation of t-value to test significance of correlation coefficient

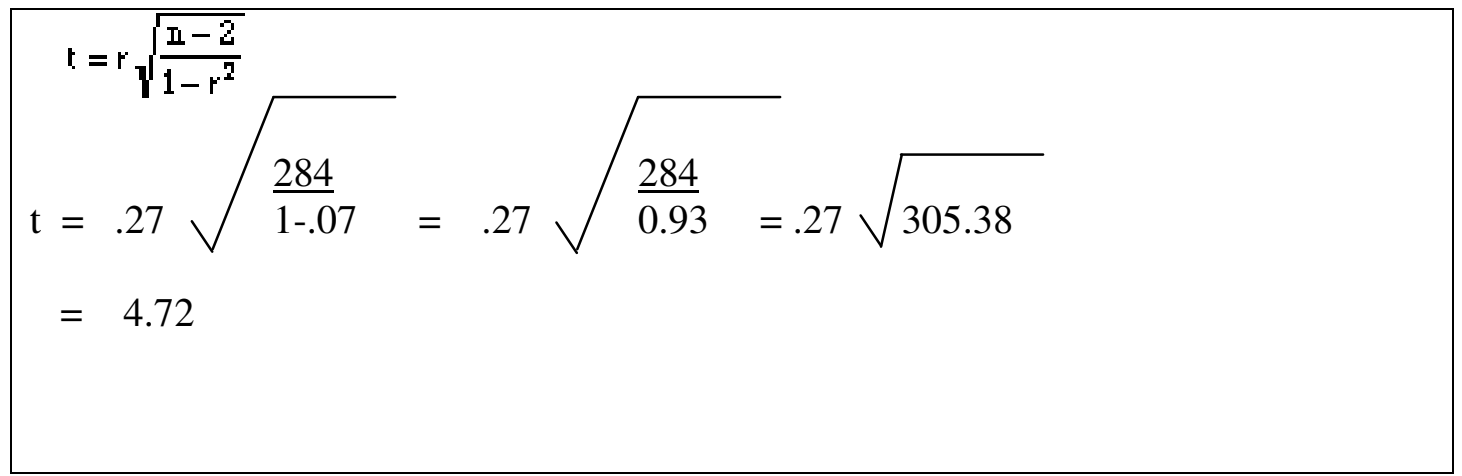

The critical value of 4.72 for the 284 degrees of freedom two-tailed test lies above the critical t-value of 3.291, confirming a significant correlation at the 99 percent level of confidence.

It is therefore apparent that Hypothesis 1, Hypothesis 2 and Hypothesis 3 will be accepted. The respondents' perception of their financial knowledge is connected to control over personal finances, as well as confidence in managing money and making investment decisions.

\section{Financial education}

Respondents were asked whether they thought that they needed financial education and whether they would participate in financial education if presented with the opportunity. Table 5 displays the total percentage of respondents who thought that they were in need of financial education and the total percentage of all the respondents who would participate in financial education if this training were provided at their workplace.

Table 5: The total respondents in need of financial education and participation therein

\begin{tabular}{|l|c|c|}
\hline & Need financial education & $\begin{array}{c}\text { Would participate in financial } \\
\text { education }\end{array}$ \\
\hline Total & $64.9 \%$ & $85.5 \%$ \\
\hline
\end{tabular}

Table 5 shows that 64.9 percent of the respondents felt that they needed financial education. Of the total number of respondents, 85.5 percent would participate in financial education if it were provided to them.

\section{Discussion}

The results of the study indicate that there is a positive correlation between adequate financial knowledge and control over personal finances, as well as confidence in managing money and making investment decisions. It can therefore be assumed that individuals who perceive that they have adequate financial knowledge feel that they have control over their personal finances; these individuals seem to be confident in managing 
their money and making investment decisions. Almost a third of the respondents indicated that they did not need financial education, which could be a concern, given that there was an overall level of dissatisfaction of $45 \%$ indicated by the respondents with regard to the adequacy of their financial knowledge.

Personal savings seem to be the most important source of finance available to entrepreneurs in creating new ventures (GEM, 2003:13). Owing to the extremely high debt ratios of consumers, savings have been left behind and almost forgotten. The consequences of excessive debt and very low savings can be destructive, as these two variables play a very important role in overall personal financial health. The literature review explains the concept of financial illiteracy amongst consumers and how ignorance regarding personal finance could influence and reduce new venture creation. Personal savings seem to be the main source of finance that start-up entrepreneurs make use of. Because of the extremely high levels of debt, insufficient personal savings seem to be available in general (Kane-Berman \& Tempest, 2007:87). This outcome could possibly lead to fewer new ventures being created due to the lack of funds (GEM, 2005:7).

Approximately a third of the respondents in this study showed high levels of dissatisfaction with their current level of financial knowledge, perceived control over finances, confidence in money management and making investment decisions. As personal savings is the principal source of venture capital in the case of most entrepreneurs (GEM, 2003:13), we might make the deduction that the lack of savings could sizeably reduce new venture creation. The lack of confidence in money management, and the lack of control that individuals experience in managing their personal finances could also have a negative effect on financial management of SMEs and could possibly lead to failure of these SMEs, should their managers have such limited knowledge of how to manage their personal and business finances. The educational background of the respondents was higher than that of most individuals in South Africa, which means that less educated individuals could have even lower levels of financial literacy and know-how.

It is vital that from a young age individuals should receive financial education in personal financial management to reduce the effects and consequences of the mismanagement of personal finances and negligent handling of debt. Services should be provided to individuals to assist them in consolidating loans and getting free of debt. It is also crucial that consumers be aware of the need to save for future purposes.

\section{Limitations of the study}

There was a limitation as regards the target population, as the population was not a representative sample of the whole South African populace. The respondents who took part in this study were all the students enrolled in management programmes at the University of the Free State's School of Management during 2005. These individuals could be regarded as being financially more knowledgeable than the average citizen as a result of their participation in business-related programmes. A possible deduction could therefore be that the typical white-collar worker without business-related tertiary 
qualifications could experience more problems concerning the management of personal finances.

There is a definite need to initiate a similar study on a national basis. Generalising from one geographical region as well as a management student sample only is a limitation. Individuals in other parts of South Africa could have different opinions and particulars.

\section{Implications for individuals wanting to start new ventures}

Due to the high levels of debts and subsequent low levels of personal savings, it is clear that personal financial education should be a prerequisite for healthy personal finances. Entrepreneurs wanting to start new ventures need to feel confident with their personal finances, as well as the finances of the new venture. It has also become clear that individuals, as well as entrepreneurs, need to start saving more in an effort to provide for the future.

\section{Directions for future research}

Research into the personal financial management area seems to be crucial, to broaden the necessary understanding of how to aid individuals in managing their debt and personal finances effectively. The results of the study could assist individuals on a personal level, as well as helping employers to support their employees in managing their debt, while enhancing their productivity through increased employee well-being. Research into this field is necessary. as there is a severe lack of information regarding South Africans' personal debt and savings, as well as personal financial information relating to age, gender, education and income. The study could also provide a basis for future research and theory development.

The following are ideas on how researchers can extend this field:

- Further research is necessary to determine spending and saving behaviour of different groups of people, such as blue-collar workers, white-collar workers, professionals, and business owners.

- In-depth research needs to be done in order to determine the consequences of inadequate financial behaviour on worker productivity and the effects thereof on the economy.

- Research is needed on the financial education of entrepreneurs and the outcomes resulting from this education on personal finances, debt and savings management and new venture finances.

- Investigations are necessary into the saving tendencies of different demographic entrepreneurial groups (classified by age, gender, qualifications and income).

\section{Conclusion}

The extremely high levels of debt and consequently low levels of personal savings could indicate a decrease in new venture creation, as personal savings is the primary source of 
financing for entrepreneurs employed in establishing new ventures. A lack of financial literacy could lead to failure of new venture, as well as personal, financial management, thus limiting new venture success. The respondents included in the study indicated that limited financial knowledge is associated with feeling less in control of personal finances, and a decrease in confidence in managing money and making investment decisions.

\section{References}

Anthes, W.L. 2004. Financial illiteracy in America: a perfect storm, a perfect opportunity. Journal of Financial Service Professionals, 58(6):49-56.

Aron, J. \& Muellbauer, J. 2000. Financial liberalization, consumption and debt in South Africa. (The Centre for the Study of African Economies Working Paper Series). [Online] Available from: http://www.bepress.com/csae/paper132.pdf [Downloaded: 2005-04-14].

Atkinson, A. \& Kempson, E. 2004. Young people, money management, borrowing and saving: a report to the Banking Code Standards Board. [Online] Available from: http://www. pfrc.bris.ac.uk/Reports/BCSB_young_people.pdf [Downloaded: 2005-09-24].

Basu. S. 2005. White Paper: Financial literacy and the life cycle. White House Conference on Aging. [Online] Available from: http://216.87.66.5/ member/govt_relation/new/loader.cfm?url=/commonspot/ security/getfile.cfm\&PageID=33231.pdf [Downloaded: 2005-06-15].

Bond, M. 2000. Understanding the benefits/wages connection: financial literacy for citizenship in a risk society. Studies in the Education of Adults, 32(1):63-77.

Chen, H. \& Volpe, R.P. 1998. An analysis of personal financial literacy among college students. Financial Services Review, 7(2):107-128.

Hair, J.F., Anderson, R.E., Tatham, R.L. \& Black, W.C. 1998. Multivariate data analysis. $5^{\text {th }}$ ed. New York: Prentice Hall.

Janda, K. 2001. Significance of the correlation coefficient: elementary statistics for political research. [Online] Available from:http://janda.org/c10/Lectures/topic06/L24-significanceR.html [Accessed: 200711-14].

Janse van Rensburg, T. 1999. Promoting personal saving in South Africa. Trade and Industry Monitor, 11:6-9.

Joo, S. 1998. Personal financial wellness and worker job productivity. Unpublished Ph.D. thesis. Blacksburg: Virginia Polytechnic and State University.

Garman, E.T., Leech, I.E. \& Grable, J.E. 1996. The negative impact of employee poor personal financial behaviours on employers. Financial Counseling and Planning, 7:157-168.

GEM (Global Entrepreneurship Monitor). 2003. South African Executive Report: 2003 Update. [Online] Available from http://www.gsb.uct.ac.za/gsbwebb/userfiles/GEM _2003_SA.pdf [Downloaded: 2007-0215].

GEM (Global Entrepreneurship Monitor). 2005. South African Report 2005. [Online] Available from: http://www.gsb.uct.ac.za/gsbwebb/userfiles/GEM2005.pdf [Downloaded: 2007-12-03].

Grawitzky, R. 2003. Pay now, worry later. South African Labour Bulletin, 27(2):52. 
Kane-Berman, J. \& Tempest, J. (Eds). 2007. South Africa Survey 2006/2007. Johannesburg: South African Institute of Race Relations.

Karlsson, N., Dellgran, P., Klingander, B. \& Gärling, T. 2004. Household consumption: influences of aspiration level, social comparison, and money management. Journal of Economic Psychology, 25(6):753769.

Kidwell, B. \& Turrisi, R. 2004. An examination of college student money management tendencies. Journal of Economic Psychology, 25(5):601-616.

Kim, J. 2000. The effects of workplace financial education on personal finances and work outcomes. Unpublished Ph.D. thesis. Blacksburg: Virginia Polytechnic Institute and State University.

Lloyd, N. 2005. Plan for your retirement, bank on living a lot longer. Sunday Times Business Times. 11 September:15.

Lorgat, M. 2003. Enabling worker finances: the effects of rising costs of living and debt on worker finances. (Unpublished paper.) South African Sociological Association. Durban.

Needham, C. 2005. Reckless spenders face a rocky retirement. Sunday Times Business Times, September 25:13.

Princeton Survey Research Associates. 1999. Consumer behaviour, experiences \& attitudes: A comparison by age groups. [Online] Available from: http://www.aarp. org/research/reference/publicopinions/aresearchimport-144-D16907.html [Accessed: 2005-10-21].

RSA MoF (Republic of South Africa. Ministry of Finance). 2006. Keynote address by the Deputy Minister of Finance, Mr. J. Moleketi, MP, at the South African Savings Institute media launch of the "Put on your savings shoes" campaign, 29 June 2006. [Online] Available from: http://www.treasury.gov.za/speeach/2006062901.pdf [Downloaded: 2006-08-15].

SARB (South African Reserve Bank). 2007. Statement of the Monetary Policy Committee 2007-12-06. [Online] Available from: http://www.reservebank.co.za/html [Accessed: 2008-01-22].

Simcock, J. 2007. An analysis of financial health and the provision of financial management services in South Africa's previously disadvantaged SME community: implications for sustainability and creditworthiness. Unpublished Masters dissertation. Cape Town: University of Cape Town.

Streeter, W.W. 2003. How's your financial literacy? ABA Banking Journal, 95(10):4.

Teichman, J.M.H., Cecconi, P.P., Bernheim, B.D., Novarro, N.K., Monga, M., DaRosa, D. \& Resnick, M.I. 2005. How do residents manage personal finances? American Journal of Surgery, 189(2):134-139.

Timmons, J.A. \& Spinelli, S. 2007. New venture creation: entrepreneurship for the $21^{\text {st }}$ Century. $7^{\text {th }}$ ed. New York: McGraw-Hill. 